\title{
Using YouTube as a Platform to Learn Social Expression
}

\author{
Suhashini A. P. Selva Raj1,2, William Hoi Theng Ann"2,3, Puspanathan A. L. Subramaniam²,4, \\ Melor Md Yunus ${ }^{2 *}$
}

${ }^{1}$ SK PosPiah, Sungai Siput (U), Malaysia

${ }^{2}$ Universiti Kebangsaan Malaysia, Bandar Baru Bangi, Malaysia

${ }^{3}$ SJK(C) New Kopisan, Gopeng, Malaysia

${ }^{4}$ SK TrolakUtara, Sungkai, Malaysia

Email: *suhashiniraj05@gmail.com

How to cite this paper: Raj, S. A. P. S., Ann, W. H. T., Subramaniam, P. A. L., \& Yunus, M. M. (2019). Using YouTube as a Platform to Learn Social Expression. Creative Education, 10, 288-296. https://doi.org/10.4236/ce.2019.102023

Received: January 11, 2019

Accepted: February 16, 2019

Published: February 19, 2019

Copyright (c) 2019 by author(s) and Scientific Research Publishing Inc. This work is licensed under the Creative Commons Attribution International License (CC BY 4.0).

http://creativecommons.org/licenses/by/4.0/

(c) (i) Open Access

\begin{abstract}
Social expression is an essential English language skill that every child should possess. In order to have a good command of the language, a child should have mastered the rules of thumb in the social skill. However, ESL learners having many constraints in social conventions as they are not native speakers of English language. In the Malaysian context, 21st century learning skill which is communicative skill has been emphasised and given utmost importance (Pandian \& Baboo, 2015). However, the social skills among the Malaysian students are at unsatisfactory level whereby the social convention has not been given top priority in Malaysian schools (Azman, 2012). This study is intended to unveil the effectiveness of using YouTube in teaching social expression. This innovation of incorporating ICT and social media platform (YouTube) in teaching social expression could be an effective blended learning approach. This is because usage of YouTube, a prominent and familiar social media platform among pupils, could trigger pupils' responses in more conducive manner as it caters their multiple intelligences (Bakar, 2007). In this intervention, 60 Year five pupils from three national schools in Perak were selected as participants. 6 YouTube videos, covering all the four language skills (Listening, Speaking, Reading and Writing) based activities were conducted to explore the effectiveness of this platform features in learning social expression. Pre and post-test and questionnaires were used as data collection methods. The main findings showed that the numbers of correct questions in post-test results increased significantly, thus portrayed understanding of social expression. As a conclusion, visualisation through YouTube is an ideal tool which could sustain participants' interest and wanting to acquire the language more.
\end{abstract}




\section{Keywords}

Social Expression, YouTube, Multiple Intelligence, Blended Learning, Communicative Responses

\section{Introduction}

The aspiration of the Malaysian education system is to create students whom are at least operationally proficient in both Bahasa Malaysia and English. Therefore, effective communication is highly encouraged in the current education system disregard of which language in order to compete globally in the 21st century (Yuen, 2015). Effective communication is defined as the ability to listen, understand, and take action on what other people say (Laurie Brown Communications, 2016). Thus, social expression is clearly representing the core elements of effective communication ability. Social expression skill is being tested in the Primary School Achievement Test or well known as UPSR under English comprehension paper 1 . However, $85 \%$ of year 6 pupils (85\%) among 3 randomly selected schools in Perak having difficulties in answering the social expression questions. This is mainly because they are lacking in terms of social conventions knowledge and vocabulary. Thus, this innovation of incorporating YouTube in teaching and learning social expression was introduced to tackle the problem identified in more engaging way for the pupils to be exposed to different utterances (Alwehaibi \& Abdulrahman, 2015).

Exploiting the features of YouTube, one of the leading video-sharing website, is believed to be able to bring out the best of resolutions for the issue highlighted. In this study, the researchers have used YouTube as a platform to create a video channel to teach samples of daily social expression according to some selected themes such as giving direction, greeting, talking over a phone, asking permission and declining and accepting invitations. This study aims to investigate the potential of YouTube to enhance students' social expression skills therefore improve their marks in the UPSR. Thus, selected pupils were trained to act out scenarios given based on the themes and the videos taken were uploaded in the YouTube. Then, the participants watched those videos and answered the writing (typed in the comment space) and speaking activities followed by the video tutorial.

\section{Literature Review}

You Tube, as a Web 2.0 aid, can be exploited to impart knowledge through observation and social interaction. According to Lindstrom (1994), students do recall and digest better when they see, hear and do. Lindstrom stated that the level of students' understanding of a subject would be when they are exposed to the multimedia presentation as a medium of instruction in the classroom. And Zahn, Pea, Hesse, \& Rosen (2010) stated that learning with the multimedia ele- 
ments such as videos have proven to increase students' understanding and an effective tool in learning. Apart from that, Bunus (2010); Greenhow and Robelia (2009) have highlighted the importance of social media in which played a crucial role in evoking students' thinking skills as well as communicate and collaborate using this social media effectively. According to the researchers, the integration of face to face classroom-based learning and via online would enhance students' language competency and communicative skills or known as blended learning approach (Taha, 2014). Willmot et al. (2011) proclaimed that utilization of video in learning, brought tremendous pedagogical benefits. The integration ICT and You Tube (a social media platform) strengthens students' centred learning (Dewitt et al., 2013) thus it enhances students' ability to communicate using the grammatic language convention.

$\mathrm{Wu}$ et al. (2002) studied the effectiveness of utilizing videos on the Internet and recommended several remedies and approaches that would be the best practise in teaching and learning process. This research reviewed the various approaches and mechanisms to stream videos and utilizing their applications. However, researches gave much importance on the influence of interactive television and video-based media on students and teachers. Whithaus and Neff (2006) revealed that teachers can utilize videos as a Web tool in teaching and learning process whereby it provided the teachers an opportunity to use videos as a mode of learning. In other words, videos can boost students' interactivity thus supports social pedagogy (Hong \& Nguyen, 2014). According to Bonk (2009), You Tube is considered as an interesting Web tool that promotes social skills and contributes to global education. Evidently, You Tube is widely used by teachers to teach English as stated by Duffy (2008). Berk (2009) proclaimed that You Tube videos not only holds students' attention, but can cater for different learning needs by addressing these aspects of multiple intelligences, specifically verbal/linguistic, visual/spatial, musical/rhythmic, and emotional intelligences. In addition, watching videos allows brain reactions in both side of the hemisphere that aids to increase and strengthen students' understanding (Ismaili, 2013). You Tube also provides authentic text/language to students, Balcikanli (2009); Watkins \& Wilkins (2011). Balcikanli pointed out that You Tube can be exploited in diverse ways to develop language skills and learn vocabulary in context.

\section{Methodology}

\subsection{Research Design}

This study is an action research based on the model of Mcniff \& Whitehead whereby the researchers investigate their own practice systematically and following certain procedure of conducting a research by identifying problem and innovate or invent an intervention to overcome the problem identified. In this study, the researchers innovate the YouTube platform to overcome the participants' mastery in social expression. The study employed quantitative method 
that analyses, merges and compares data from both sources, questionnaires to support the findings from the pre and post-test (Figure 1).

\subsection{Respondents}

To tabulate the date on the effectiveness of using YouTube in teaching social expression, a total of 60 respondents in Year 5 who practices different mother tongues, such as Mandarin, Malay Language, and Temiar (aboriginal language) were selected randomly to undergo the pre-test and post-test The respondents were taught extensively via YouTube on social convention that incorporates the correct language convention and utterances. Then, the respondents were tested on the social convention skills (Table 1).

\section{Procedure}

The action research was conducted for 3 weeks. The respondents were randomly selected from three national types of schools. A total of 20 pupils were selected through random sampling in each school. The selected pupils were given pre-test whereby the scores were recorded. Then, the intervention was carried out after the school hours where the pupils were brought to the computer lab or to self-access room. The videos were being played and the post video activities were conducted to track pupils' mastery on the particular social expression themes. Five themes were covered across three weeks. Subsequently, a post-test was given after the respondents from each school undergo the intervention. Finally, the respondents were given questionnaires to obtain their perceptions and understanding on using YouTube to learn the social expression and the utterances. Questionnaires were constructed based on respondents' proficiency and ability to describe the elements that would be the core factor in determining the effectiveness of using ICT (YouTube) in teaching the social expression as stated by Bakar (2007).

\subsection{Pre and Post-Test}

One of the instruments for data collection adopted by the researchers was pre and post-test. The questions designed for the pre and post-test were identical to prove the effectiveness of using YouTube in teaching social expression. Moreover, the identical questions were constructed to ensure the validity and reliability of the study. The pre-test was given to the participants before the intervention while the post-test was given after the intervention where the respondents would be taught extensively incorporating ICT via YouTube in teaching social expression. Both tests construct contain 10 subjective questions on social expression that carries 2 marks each.

\subsection{Questionnaire}

The other instrument for data collection used was questionnaires. The data collection instrument was constructed based on the Likert's Scale Model. This part contains 9 close-ended questions which were categorised by 3 pre-determined 
themes concerning participants' perception towards the use of YouTube in learning social expression, their social conventions towards the improvement after the innovation and acceptance of the participants of the intervention for future use. Each of the questions has 5 scales, ranking from strongly disagree/disagree/neutral/agree/ strongly agree.

\section{Results}

The scores for the tests involved in this study are plotted in the table below. In both the pre-test and post-test, they consist of 10 questions with each bearing 2 marks, a total 20 marks in total for a test. The marking rubrics are: 2 marks for complete and accurate answer, 1 mark is awarded for incomplete/partially correct answers and 0 marks is for the wrong answers or blanks (Table 2).

\subsection{Pre and Post Test Results}

YouTube video usage is effective in improving social expression learning. The total score of all the participants, 60 pupils, after answering all the 10 questions (20 marks) during pre-test, is 555 marks. The average score of each participant is 9.25 marks out of 20 marks, which can be conclude as 5 questions out of 10 questions correctly during pre-test (Table 3 ).

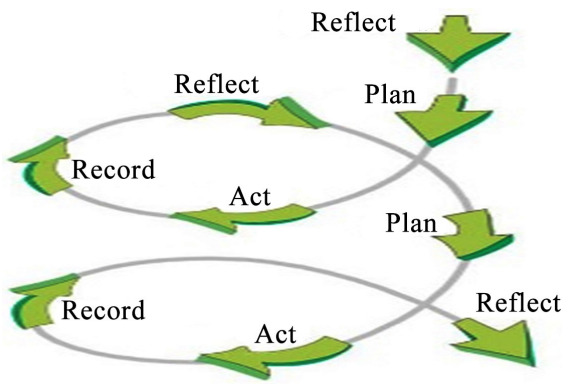

Figure 1. McNiff and Whitehead action research model.

Table 1. Basic information about the subjects.

\begin{tabular}{lllll}
\hline School & Age & $\begin{array}{l}\text { Group of } \\
\text { proficiency }\end{array}$ & $\begin{array}{l}\text { Geographical } \\
\text { location }\end{array}$ & $\begin{array}{l}\text { Accessibility of } \\
\text { ICT }\end{array}$ \\
\hline 1) Urban school, Gopeng, Perak & 11 & Low & Rural & Limited \\
2) Suburban, Sungkai, Perak & 11 & Mix Ability & Urban & Adequate \\
3) Rural, Sungai Siput, Perak & 11 & Low/IntermediateSuburban & Adequate \\
\hline
\end{tabular}

Table 2. Comparison of results in pre-test and post-test.

\begin{tabular}{lcccc}
\hline School & $\begin{array}{l}\text { Pre-test } \\
\text { scores of } 60 \\
\text { participants }\end{array}$ & $\begin{array}{l}\text { Means of } \\
\text { pre-test score } \\
\text { (out of 20 pupils) }\end{array}$ & $\begin{array}{l}\text { Post test } \\
\text { scores of 60 } \\
\text { participants }\end{array}$ & $\begin{array}{l}\text { Means of } \\
\text { post test scores } \\
\text { (20 pupils) }\end{array}$ \\
\hline Urban school, Gopeng, Perak & 235 & 11.75 & 340 & 17 \\
Sub-urban, Sungkai, Perak & 200 & 10 & 313 & 15.65 \\
Rural, Sungai Siput, Perak & 120 & 6 & 300 & 15 \\
Total & 555 & 9.25 & 953 & 15.88
\end{tabular}


Table 3. Questionnaire.

\begin{tabular}{|c|c|c|c|c|c|}
\hline & $\begin{array}{l}\text { Strongly } \\
\text { disagree } \\
\mathrm{n}(\%)\end{array}$ & $\begin{array}{l}\text { Disagree } \\
\mathrm{n}(\%)\end{array}$ & $\begin{array}{l}\text { Neutral } \\
\mathrm{n}(\%)\end{array}$ & $\begin{array}{l}\text { Agree } \\
\mathrm{n}(\%)\end{array}$ & $\begin{array}{l}\text { Strongly } \\
\text { agree } \\
\mathrm{n}(\%)\end{array}$ \\
\hline \multirow{2}{*}{\multicolumn{6}{|c|}{$\begin{array}{l}\text { Theme 1: Perception towards the use of } \\
\text { YouTube to learn social expression in ESL } \\
\text { classroom } \\
\text { Questions: }\end{array}$}} \\
\hline & & & & & \\
\hline $\begin{array}{l}\text { 1) Learning social expression through YouTube } \\
\text { is more fun than traditional classroom }\end{array}$ & $\begin{array}{l}0 \\
(0.0 \%)\end{array}$ & $\begin{array}{l}5 \\
(8.3 \%)\end{array}$ & $\begin{array}{l}4 \\
(6.7 \%)\end{array}$ & $\begin{array}{l}8 \\
(13.3 \%)\end{array}$ & $\begin{array}{l}43 \\
(71.7 \%)\end{array}$ \\
\hline $\begin{array}{l}\text { 2) I like watching the videos in YouTube } \\
\text { channels }\end{array}$ & $\begin{array}{l}0 \\
(0.0 \%)\end{array}$ & $\begin{array}{l}0 \\
(0.0 \%)\end{array}$ & $\begin{array}{l}0 \\
(0.0 \%)\end{array}$ & $\begin{array}{l}7 \\
(11.7 \%)\end{array}$ & $\begin{array}{l}53 \\
(88.3 \%)\end{array}$ \\
\hline $\begin{array}{l}\text { 3) I like to read the sentences in the } \\
\text { videos }\end{array}$ & $\begin{array}{l}0 \\
(0.0 \%)\end{array}$ & $\begin{array}{l}1 \\
(1.7 \%)\end{array}$ & $\begin{array}{l}2 \\
(3.3 \%)\end{array}$ & $\begin{array}{l}18 \\
(30.0 \%)\end{array}$ & $\begin{array}{l}39 \\
(65.0 \%)\end{array}$ \\
\hline $\begin{array}{l}\text { 4) Visuals help me to understand the content } \\
\text { better }\end{array}$ & $\begin{array}{l}0 \\
(0.0 \%)\end{array}$ & $\begin{array}{l}4 \\
(6.7 \%)\end{array}$ & $\begin{array}{l}4 \\
(6.7 \%)\end{array}$ & $\begin{array}{l}7 \\
(11.7 \%)\end{array}$ & $\begin{array}{l}45 \\
(75.0 \%)\end{array}$ \\
\hline \multicolumn{6}{|l|}{$\begin{array}{l}\text { Theme 2: Respondent's social convention } \\
\text { towards the improvement after the innovation } \\
\text { Questions: }\end{array}$} \\
\hline $\begin{array}{l}\text { 1) YouTube videos have aided interactions } \\
\text { among individuals }\end{array}$ & $\begin{array}{l}2 \\
(3.3 \%)\end{array}$ & $\begin{array}{l}1 \\
(1.7 \%)\end{array}$ & $\begin{array}{l}3 \\
(5.0 \%)\end{array}$ & $\begin{array}{l}15 \\
(25.0 \%)\end{array}$ & $\begin{array}{l}39 \\
(65.0 \%)\end{array}$ \\
\hline $\begin{array}{l}\text { 2) YouTube videos improves speaking } \\
\text { skills }\end{array}$ & $\begin{array}{l}0 \\
(0.0 \%)\end{array}$ & $\begin{array}{l}0 \\
(0.0 \%)\end{array}$ & $\begin{array}{l}5 \\
(8.3 \%)\end{array}$ & $\begin{array}{l}7 \\
(11.7 \%)\end{array}$ & $\begin{array}{l}48 \\
(80.0 \%)\end{array}$ \\
\hline $\begin{array}{l}\text { 3) YouTube video improves on reading } \\
\text { skill. }\end{array}$ & $\begin{array}{l}0 \\
(0.0 \%)\end{array}$ & $\begin{array}{l}5 \\
(8.3 \%)\end{array}$ & $\begin{array}{l}4 \\
(6.7 \%)\end{array}$ & $\begin{array}{l}8 \\
(13.3 \%)\end{array}$ & $\begin{array}{l}43 \\
(71.7 \%)\end{array}$ \\
\hline $\begin{array}{l}\text { 4) YouTube video improves writing } \\
\text { skill. }\end{array}$ & $\begin{array}{l}0 \\
(0.0 \%)\end{array}$ & $\begin{array}{l}1 \\
(1.7 \%)\end{array}$ & $\begin{array}{l}2 \\
(3.3 \%)\end{array}$ & $\begin{array}{l}5 \\
(8.3 \%)\end{array}$ & $\begin{array}{l}52 \\
(86.7 \%)\end{array}$ \\
\hline $\begin{array}{l}\text { Theme 3: continuation of using YouTube video } \\
\text { to learn social expression }\end{array}$ & & & & & \\
\hline $\begin{array}{l}\text { Questions: } \\
\text { 1) Will you continue using YouTube video in } \\
\text { learning social expression? }\end{array}$ & 0 & 0 & 0 & $\begin{array}{l}2 / 60 \\
\text { pupils } \\
(3.3 \%)\end{array}$ & $\begin{array}{l}58 / 60 \\
\text { Pupils } \\
(96.7 \%)\end{array}$ \\
\hline
\end{tabular}

The total score of the participants had changed after underwent the innovation whereby the total score had increased to 953 marks during the post-test compared to the 555 marks in the pre-test. This roughly can be defined as each participant obtained a mark of 15.88 marks or 8 questions out of 10 questions correctly. Hence, it is proclaimed by Balcikanli (2009) watching videos allows brain reactions in both hemisphere, that aids to increase and strengthen students' understanding (Table 2).

\subsection{Perception towards the Use of YouTube to Learn Social Expression in ESL Classroom}

Learning social expression via YouTube videos are more interesting than the traditional methods. From the data of the questionnaire, resulted, 43 out of 60 pupils (71.7\%) (Theme 1 Question 1) do agree that learning social expression is fun rather than the traditional chalk-and-talk method (Table 3). 


\subsection{Respondent's Social Convention towards the Improvement after the Innovation}

The pupils agree that by using this innovation, it does help them in improving their social skills as shown in Theme 2 Question 1 where 39 pupils out of 60 $(65.0 \%)$ strongly agrees on this statement while $15(25.0 \%)$ more pupils agree on this statement. As an overall conclusion for the findings in Theme 2, 90.4\% of the pupils agree and strongly agree that the innovation is helpful in improving their language level. According to Bonk (2009), YouTube is considered as an interesting web tool that could promote social skills and also contribute to global education (Table 3). The result finding also aligns with the statement of Silviyanti \& Aceh (2014) where YouTube is indeed effective where it aids students to understand better in the process of English learning.

\subsection{Continuation of Using YouTube Video to Learn Social Expression}

Theme 3 explains on the willingness of pupils to try the innovation again in near future and based on our deciphering of data, it can be said that, out of 60 pupils across three schools, 58 of the pupils or $96.7 \%$ of the pupils strongly agree on the question itself (Table 3).

\section{Discussion}

Based on all the data collected, it is safe to say that the innovation of learning social expression through the usage of YouTube videos is indeed effective and attractive towards the learners. This aligns with the research of Yunus et al. (2013) where it is stated that ICT improves English learning progress. Yunus \& Salehi (2012) also mentioned that ICT intergration in English Language learning is indeed an effective way to boost one's language learning progress. As a comparison to the previous researches, this can be seen from both the pre-test and post-test scores of the participants where there is a significant increase in the post-test scores compared to the pre-test scores. It is shown in Table 1 in data analysis. Besides that, the learners did show their interests towards this innovation and they hold the opinion of the innovation is indeed helping them to learn English better and they saw significant changes in their learning portrayed in Table 2 in data analysis. The result findings are parallel with the results of research from Wael (2016) where it is proven that YouTube is effective in English learning process.

\section{Conclusion}

In conclusion, using YouTube as a platform in teaching social expression is proved to be accommodating and efficient based on the post-test results and interview transcription. The usage of authentic videos in teaching and learning social expression has definitely boosted up the pupils' interest and confidence to learn more (Olasina, 2017). Thus, other educators could take into consideration 
in using YouTube as a trustable platform in teaching and learning (T\&L) social expression so that the process can be more interactive and meaningful. Further researches can be done in the future to enhance the methodology of teaching language especially the language convention that would aim to improvise students' speaking skills and as well as writing apprehension.

In addition, support from parents in accepting the new paradigm of T\&L and policy makers to provide better facilities in all schools in Malaysia would make this innovation effort more success.

\section{Conflicts of Interest}

The authors declare no conflicts of interest regarding the publication of this paper.

\section{References}

Alwehaibi, H., \& Abdulrahman, P. (2015). The Impact of Using YouTube in EFL Classroom on Enhancing. Journal of College Teaching and Learning, 12, 121-126. https://doi.org/10.19030/tlc.v12i2.9182

Azman, H. (2012). Implementation and Challenges of English Language Education Reform in Malaysian Primary Schools. 3L: Language, Linguistics, Literature, 22, 65-78.

Bakar, N. A. (2007). English Language Activities in Computer-Based Learning Environment: A Case Study in ESL Malaysian Classroom. GEMA Online Journal of Language Studies, 7, 33-49.

Balcikanli, C. (2009). Long Live, YouTube: L2 Stories about YouTube in Language Leaning. E-Proceeding of the International Online Language Conference (IOLC).

Berk, R. (2009). Multimedia Teaching with Video Clips: TV, Movies, YouTube, and MTVU in the College Classroom. International Journal of Technology in Teaching and Learning, 5, 1-21.

Bonk, J. (2009). The World Is Open: How Web Technology Is Revolutionizing Education. San Francisco: Jossey-Bass.

Bunus, P. (2010). The Social Network Classroom Technology Enhanced Learning. Quality of Teaching and Educational Reform, 73, 517-524.

Dewitt, D., Alias, N., Siraj, S., Yaakub, M. Y., Ayob, J., \& Ishak, R. (2013). The Potential of Youtube for Teaching and Learning in the Performing Arts. Procedia-Social and Behavioral Sciences, 103, 1118-1126. https://doi.org/10.1016/j.sbspro.2013.10.439

Duffy, P. (2008). Engaging the YouTube Google-Eyed Generation: Strategies for Using Web 2.0 Teaching and Learning. Electronic Journal of e-Learning, 6, 173-182.

Greenhow, C., \& Robelia, B. (2009). Informal Learning and Identity Formation in Online Social Networks. Learning, Media and Technology, 34, 119-140.

https://doi.org/10.1080/17439880902923580

Hong, N., \& Nguyen, T. (2014). An Exploratory Study of ICT Use in English Language by Dang Hoang Tri. Teaching English with Technology, 14, 32-46.

Ismaili, M. (2013). The Effectiveness of Using Movies in the EFL Classroom-A Study Conducted at South East European University. Academic Journal of Interdisciplinary Studies, 2, 121-132. https://doi.org/10.5901/ajis.2012.v2n4p121

Laurie Brown Communications (2016). What Is Effective Communication? https://auriebrown.com/communication-skills/what-is-effective-communication 
Lindstrom, R. (1994). The Business Week Guide to Multimedia Presentations: Create Dynamic Presentations That Inspire. New York: McGraw Hill.

Olasina, G. (2017). An Evaluation of Educational Values of YouTube Videos for Academic Writing. The African Journal of Information Systems, 9, Article 2.

Pandian, A., \& Baboo, S. B. (2015). Digital Life Worlds and Designers of Literacy Practices in Malaysian Schools. In B. Cope, \& A. Kalantzis (Eds.), Pedagogy of Multiliteracies: Learning by Design (pp. 231-225). Basingstoke, UK: Palgrave Macmillan.

Silviyanti, T. M., \& Aceh, B. (2014). Looking into EFL Students' Perceptions in Listening by Using English Movie Videos on YouTube. Studies in English Language and Education, 1, 42-58. https://doi.org/10.24815/siele.v1i1.1119

Taha, A. M. (2014). Exploring Motivational Design and Motivation Types Facilitated by an Online Support System for Learning Literature. GEMA Online Journal of Language Studies, 14, 109-122. https://doi.org/10.17576/GEMA-2014-1402-08

Wael, A. A. (2016). The Effective Use of You Tube Videos for Teaching English Language in Classrooms. International Journal of English Language and Linguistics Research, 4, 32-47.

Watkins, J., \& Wilkins, M. (2011). Using YouTube in the EFL Classroom. Language Education in Asia, 2, 113-119. https://doi.org/10.5746/LEiA/11/V2/I1/A09/Watkins_Wilkins

Whithaus, C., \& Neff, M. J. (2006). Contact and Interactivity: Social Constructionist Pedagogy in a Video-Based, Management Writing Course. Technical Communication Quarterly, 15, 431-456. https://doi.org/10.1207/s15427625tcq1504_2

Willmot, P., Bramhall, M., \& Radley, K. (2011). Introducing Audio-Visual Media for Inspirational Learning and Positive Engagement. SEFI International Conference on Engineering Education, Lisbon, Portugal, 420-426.

$\mathrm{Wu}, \mathrm{D}$. P. et al. (2002). Streaming Video over the Internet: Approaches and Directions. IEEE Transactions on Circuits and Systems for Video Technology, 11, 282-300.

Yuen, F. (2015). Teachers' and Students' Perceptions towards the Use of YouTube Videos in an English Classroom. Hong Kong: University of Hong Kong.

Yunus, M., \& Salehi, H. (2012). The Effectiveness of Facebook Groups on Teaching and Improving Writing: Students' Perceptions. Journal of Education and Information Technologies, 1, 87-96.

Yunus, M., Nordin, N., Salehi, H., Embi, M. A., \& Salehi, Z. (2013). The Use of Information and Communication Technology (ICT) in Teaching ESL Writing Skills. English Language Teaching, 6, 1-8. https://doi.org/10.5539/elt.v6n7p1

Zahn, C., Pea, R., Hesse, F. W., \& Rosen, J. (2010). Comparing Simple Advanced Video Tools as Supports for Complex Collaborative Design Processes. The Journal of the Learning Sciences, 19, 403-440. https://doi.org/10.1080/10508401003708399 